\title{
Interaction between 3,5-diacetyl-1,4-dihydropyridines and ampicillin, and erythromycin on different $E$. coli strains
}

\author{
Györgyi Gunics ${ }^{\mathrm{a}}$, Sándor Farkas ${ }^{\mathrm{a}}$, Noboru Motohashi ${ }^{\mathrm{b}}$,*, Anamik Shah ${ }^{\mathrm{c}}$, \\ Gaveriya Harsukh ${ }^{\mathrm{c}}$, Masami Kawase ${ }^{\mathrm{d}}$, Joseph Molnár ${ }^{\mathrm{a}}$ \\ ${ }^{a}$ Department of Microbiology, Albert Szent-Györgyi Medical University, Szeged, Hungary \\ ${ }^{\mathrm{b}}$ Meiji Pharmaceutical University, 2-522-1 Noshio, Kiyose, 2048588 Tokyo, Japan \\ ${ }^{\mathrm{c}}$ Department of Chemistry, Saurashtra University, University Road, Rajkot, India \\ ${ }^{\mathrm{d}}$ Faculty of Pharmaceutical Sciences, Josai University, Sakado, Saitama, Japan
}

Received 12 December 2001; accepted 9 January 2002

\begin{abstract}
Eleven analogues of nifedipine (NP) showed synergistic interactions with ampicillin (Ap) and erythromycin (Er) on Escherichia coli K12LE140/F'lac. The antibacterial effect of Ap was enhanced by most analogues but compound (G9) and ( \pm )-verapamil (VP) were antagonistic. Two of the 11 compounds (G7, G8) were synergistic with Er and four were additive. With a sensitive clinical isolate of $E$. coli Gy-1/Ap sens $\mathrm{Er}_{\mathrm{res}}$, compound G1 antagonized the antibacterial effect of Ap and a synergistic effect was found in the combination of Er with G4, G5, G6 or G7. None of the drugs had any effect on a multidrug resistant (MDR) clinical isolate of

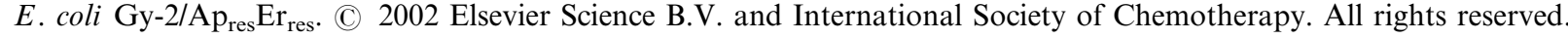

Keywords: Synergism; Acetyldihydropyridines; Antibiotics; Resistance modifiers; E. coli

\section{Introduction}

Various studies have been made to increase the efficiency of antimicrobial agents. A combination of methdiazine $(\mathrm{Md})$ a phenothiazine derivative and streptomycin (Sm), ampicillin (Ap), erythromycin (Er) or tetracycline $(\mathrm{Tc})$ was synergistic against Vibrio cholerae 14033 [1]. Similarly, significant synergism was found between promazine $(\mathrm{Pr})$, a phenothiazine derivative possessing antimicrobial activity, and $\mathrm{Sm}, \mathrm{Ap}$ and $\mathrm{Er}$ or Tc against Salmonella typhimurium NCTC 74 infection in mice [2].

In a previous study, we found that $( \pm)$-verapamil (VP) plus promethazine were effective resistance modifiers on a laboratory strain of Escherichia coli by plasmid elimination [3].

The resistance modifier effect of VP is seen in bacteria [4], fungi [5,6], protozoa [7] and cancer cells [8] but adverse effects occurred. To improve specificity, new

* Corresponding author. Tel./fax: +81-424-95-8953

E-mail address: motohasi@my-pharm.ac.jp (N. Motohashi). nifedipine (NP) analogues were synthesized on the basis of previous results [9] and tested on a laboratory strain of $E$. coli and two clinical isolates. The interaction between antibiotics and newly synthetized NP analogues were studied and evaluated by the chequerboard test.

\section{Materials and methods}

\subsection{Chemicals}

Eleven acetyldihydropyridines AcDHP (G1-11) of $\mathrm{NP}$ analogue were synthesized as previously described [9] (Fig. 1).

\subsection{Antibiotics and resistance modifiers}

The following antibiotics were obtained from the companies indicated: Ap (Beechaem Research Laboratories, England); Er (Richter Gedeon RT, Budapest, Hungary).

The resistance modifiers were obtained from the companies indicated; $( \pm)$-VP (Chinoin, Budapest, Hun- 
<smiles>[R]c1ccccc1C(C(C)=O)c1c(C)[nH]c(C)c1C(C)=O</smiles>

[G1], $\mathrm{R}=3-\mathrm{NO}_{2}$

[G2], $\mathrm{R}=3-\mathrm{PhO}$

[G3], $\mathrm{R}=3-\mathrm{Cl}$

[G4], $\mathrm{R}=4-\mathrm{OH}, 3-\mathrm{CH}_{3} \mathrm{O}$

[G5], $\mathrm{R}=4-\left(\mathrm{CH}_{3}\right)_{2} \mathrm{~N}$

[G6], $\mathrm{R}=4-\mathrm{CH}_{3} \mathrm{O}$

[G7], $\mathrm{R}=4-\mathrm{Cl}$

[G8], $\mathrm{R}=3-\mathrm{CH}_{3} \mathrm{~S}$

[G9], $\mathrm{R}=3-\mathrm{Br}$

[G10], $\mathrm{R}=4-\mathrm{Cl}$

[G11], $\mathrm{R}=2-\mathrm{NO}_{2}$<smiles>CC(=O)C(C)=C(C(C)=O)C1C(C)=C(C)NC(C)=C1[N+](=O)[O-]</smiles>

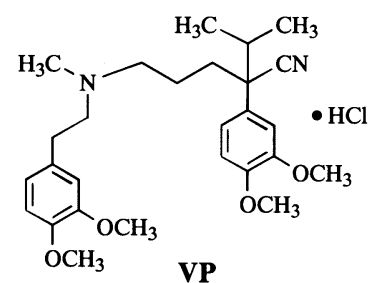

Fig. 1. Structures of 3,5-diacetyl-1,4-dihydropyridines (G1-11), ( \pm )VP and NP.

gary); NP (Aldrich Chemical Co., Inc., Milwaukee, WI, USA).

\subsection{Bacterial strains}

A laboratory strain of $E$. coli K12LE140/F'lac and two clinical isolates ( $E$. coli $\mathrm{Gy}-1 / \mathrm{Ap}_{\mathrm{sen}} \mathrm{Er}_{\mathrm{res}}$ and $E$. coli Gy-2/Ap res $_{\text {res }}$ ) were kindly provided by the public health institute of Csongrad county.

\subsection{Measurement of antibacterial activity}

The antibacterial effect of the tested compounds was studied in modified minimal tryptone yeast extract
(MTY) liquid media [4], containing $1.0 \mathrm{~g} \mathrm{NH}_{4} \mathrm{Cl}, 7.0 \mathrm{~g}$ $\mathrm{K}_{2} \mathrm{HPO}_{4}, 3.0 \mathrm{~g} \mathrm{NaH}_{2} \mathrm{PO}_{4}, 0.8 \mathrm{~g} \mathrm{NaCl}, 1.0 \mathrm{~g}$ D-glucose, $10.0 \mathrm{~g}$ Bacto trytone (Difco) and $1.0 \mathrm{~g}$ yeast extract (Difco) in 1.01 distilled water at $\mathrm{pH}$ 7.2.

An overnight preculture of the laboratory strain and two clinical isolates of $E$. coli were diluted $10^{-4}$-fold and $0.1 \mathrm{ml}$ (ca. $5 \times 10^{3}$ bacteria) was inoculated into 5.0 $\mathrm{ml}$ of MTY broth containing various concentrations of the different compounds. The cultures were grown at $37{ }^{\circ} \mathrm{C}$ without shaking. Minimum inhibitory concentrations (MIC) were read after $24 \mathrm{~h}$ incubation.

Three bacterial strains were tested by the microdilution chequerboard technique described by Eliopoulus and moellering [10]. Briefly, bacterial dilutions from the logarithmic-growth phase were prepared and subsequently distributed into micrometer trays containing various drug regimen concentrations. The final inoculum size in the micrometer trays was approximately $10^{5}$ colony forming unit (CFU)/ml.

Inoculated micrometer trays were incubated at $37{ }^{\circ} \mathrm{C}$ for a period of $24 \mathrm{~h}$ and were then read for inhibition of bacterial growth. In order to evaluate the outcome of the drug combination, fractional inhibitory concentration (FIC) indices were calculated as $\mathrm{FIC}_{\mathrm{A}}+\mathrm{FIC}_{\mathrm{B}}$, when $\mathrm{FIC}_{\mathrm{A}}$ and $\mathrm{FIC}_{\mathrm{B}}$ represent the minimum concentrations that inhibited inoculum growth for drugs $A$ and $B$, respectively [9]. Individual chequerboard runs were replicates, a mean FIC index was calculated and applied to a commonly utilized definition of synergy, and classified as either synergistic $(\leq 0.5)$, additive $(0.51-$ 1.0 ), indifferent $(1.01$ but $\leq 4.0$ ), or antagonistic (above 4.0) (Table 1).

Table 1

MICs by synergistic effect of 3,5-acetyl-1,4-dihydropyridines $5 \mu \mathrm{g} / \mathrm{ml}$ and ampicillin (Ap) or $8 \mu \mathrm{g} / \mathrm{ml}$ erythromycin (Er) sensitive and resistant $E$. coli strains

\begin{tabular}{|c|c|c|c|c|c|c|}
\hline & \multicolumn{6}{|l|}{ E. coli } \\
\hline & \multicolumn{2}{|c|}{ K12LE140/F'lac } & \multicolumn{2}{|c|}{$\mathrm{Gy}-1 / \mathrm{Ap}_{\mathrm{sens}} \mathrm{Er}_{\mathrm{res}}$} & \multicolumn{2}{|c|}{$\mathrm{Gy}-2 / \mathrm{Ap}_{\text {sens }} \mathrm{Er}_{\text {res }}$} \\
\hline & AMP & ERY & AMP & ERY & Ap & $\mathrm{Er}$ \\
\hline Antibiotic alone & 4 & 8 & 8 & 64 & 256 & $>64$ \\
\hline$+\mathrm{G} 1$ & 1 & 8 & 64 & 32 & $>64$ & $>64$ \\
\hline$+\mathrm{G} 2$ & 2 & 4 & 8 & 32 & $>64$ & $>64$ \\
\hline$+\mathrm{G} 3$ & 1 & 4 & 8 & 32 & $>64$ & $>64$ \\
\hline$+\mathrm{G} 4$ & 1 & 8 & 8 & 16 & $>64$ & $>64$ \\
\hline$+\mathrm{G} 5$ & 2 & 8 & 8 & 16 & $>64$ & $>64$ \\
\hline$+\mathrm{G} 6$ & 2 & 8 & 8 & 16 & $>64$ & $>64$ \\
\hline$+\mathrm{G} 7$ & 1 & 2 & 8 & 16 & $>64$ & $>64$ \\
\hline$+\mathrm{G} 8$ & 1 & 2 & 8 & 32 & $>64$ & $>64$ \\
\hline + G9 & $>8$ & 8 & 8 & 32 & $>64$ & $>64$ \\
\hline$+\mathrm{G} 10$ & 1 & 4 & 8 & 32 & $>64$ & $>64$ \\
\hline$+\mathrm{G} 11$ & 1 & 4 & 8 & 32 & $>64$ & $>64$ \\
\hline$+( \pm)-V P$ & 32 & 4 & 4 & 32 & $>64$ & $>64$ \\
\hline$+\mathrm{NP}$ & 2 & 4 & 8 & 32 & $>64$ & $>64$ \\
\hline
\end{tabular}




\section{Results and discussion}

\subsection{Antibacterial activity of Ap, AcDHP (G1-11), VP, $N P$ and $E r$}

MIC values of AcDHP after $24 \mathrm{~h}$ were measured on three different $E$. coli strains and the results are shown in Table 1. No antibacterial effect was seen by the nonantibiotics up to a concentration of $100 \mu \mathrm{g} / \mathrm{ml}$. Table 1 shows the results of the chequerboard studies.

\subsection{Combination effect of AcDHP (G1-11) with $A p$}

A synergistic effect of AcDHP was seen with Ap against $E$. coli K12LE140/F'lac after $24 \mathrm{~h}$, when combination with seven AcDHP reduced the Ap MIC to $1 \mathrm{mg} / \mathrm{l}$ and the MIC of NP to $2 \mathrm{mg} / \mathrm{l}$. Two compounds G9 (MIC $>8 \mathrm{mg} / \mathrm{l}$ ) and VP (MIC: $32 \mathrm{mg} / \mathrm{l}$ ) were less effective than the others. The most effective compounds were as follows: G1, G3, G4, G7, G8, G10 and G11.

The MICs of Ap against a clinical isolate (E. coli Gy$\left.1 / \mathrm{Ap}_{\text {sens }} \mathrm{Er}_{\mathrm{res}}\right)$ after $24 \mathrm{~h}$ with combination of $\mathrm{G} 1$ were antagonistic (MIC for Ap $64 \mathrm{mg} / \mathrm{l}$ ) (Table 1). Ten other AcDHP (G1-11) (MIC: $8 \mathrm{mg} / \mathrm{l})$ and NP (MIC: $8 \mathrm{mg} / \mathrm{l})$ were not synergistic and only VP (MIC: $4 \mathrm{mg} / \mathrm{l}$ ) had an additive effect.

\subsection{Combination effect of AcDHP (G1-11) with Er}

AcDHP (G1-11) had a synergistic effect with $\mathrm{Er}$ against $E$. coli K12LE140/F'lac after 24 h, the MICs of G7 (MIC: $2 \mathrm{mg} / \mathrm{l}$ ) and G8 (MIC: $2 \mathrm{mg} / \mathrm{l}$ ) were synergistic whereas the MIC values of G2, G3, G10, G11, VP and $\mathrm{NP}$ were additive ( $4 \mathrm{mg} / \mathrm{l})$. The compounds $\mathrm{G} 1, \mathrm{G} 4, \mathrm{G} 5$, G6 and G9 were ineffective in combination with $\mathrm{Er}$ against $E$. coli K12LE140/F'lac strain (Table 1). Compound $\mathrm{G} 7$ was the most effective of the eleven AcDHP (G1-11), VP and NP with Ap or Er against E. coli K12LE140/F'lac after $48 \mathrm{~h}$ (Table 1).

Combination of Er with eleven AcDHP (G1-11) (MIC: $16-32 \mathrm{mg} / \mathrm{l}$ ), VP (MIC: $32 \mathrm{mg} / \mathrm{l}$ ) and NP (MIC: $32 \mathrm{mg} / \mathrm{l}$ ) had no effect on the MIC of Er (Table 1).

The combinations of AcDHP (G1-11) with the two antibiotics against clinical isolate E. coli Gy-2/Ap $\mathrm{Ares}_{\mathrm{Eres}}$ showed no differences (Table 1).

\section{Conclusions}

Synergistic or additive effects of AcDHP (G1-11) with Ap or Er have been shown on E. coli K12LE140/ F'lac and E. coli Gy-1/Ap sens $E_{\text {res }}$ but, not on E. coli $\mathrm{Gy}-2 / \mathrm{Ap}_{\mathrm{res}} \mathrm{Er}_{\text {res. }}$. These effects of synergistic or additive combinations are supported by additional experiments, in which trimeprazine exhibited significant synergistic antimicrobial activity when combined with either tri- methoprim or sulfathiazole [11]; development of crossresistance by administration of non antibiotics with antibiotics has also been repeated [12]. The present paper clearly defines the effects of combinations of AcDHP (G1-11) analogues with Ap or Er, which are of some interest.

\section{Acknowledgements}

This study was supported by the foundation for cancer research of Szeged (Szegedi Rákkutatásért Alapítvány), Szeged, Hungary.

\section{References}

[1] Chattopadhyay D, Dastidar SG, Chakrabarty AN. Antimicrobial properties of methdilazine and its synergism with antibiotics and some chemotherapeutic agents. Arzneim-Forsch/Drug Res 1988;38:869-72.

[2] Dastidar SG, Chakraborty P, Mookerjee M, Ganguly M, Chakrabarty AN. Studies on the existence of synergism between different antibiotics and phenothiazine tranqullizer, promazine, possessing antimicrobial property. Acta Microbiol Immunol Hung 1994;41:41-9.

[3] Gunics G, Motohashi N, Amaral L, Farkas S, Molnár J. Interaction between antibiotics and non-conventional antibiotics on bacteria. Int J Antimicrob Agents 2000;14:239-42.

[4] Molnár J, Gunics G, Mucsi I, et al. Antimicrobial and immunomodulating effects of some phenolic glycosides. Acta Microbiol Hung 1989;36:425-32.

[5] Bibikova MV, Rybakova AM, Vostrov SN, Spiridonova IA, Ivanitskaia LP. A system for screening natural immunosuppressors. Antibiot Khimioter 1991;36(Suppl 3):17-20 (in Russian).

[6] Calvert CM, Sanders D. Inositol trisphosphate and independent $\mathrm{Ca}^{2+}$ mobilization pathways at the vacuolar membrane of Candida albicans. J Biol Chem 1995;270:7272-80.

[7] Martin SK, Oduola AMJ, Milhous WK. Reversal of chloroquine resistance in Plasmodium falciparum by verapamil. Science 1987;235:899-901.

[8] Molnár J, Szabó D, Mándi Y, et al. Multidrug resistance reversal in mouse lymphoma cells by heterocyclic compounds. Anticancer Res 1998;18:3033-8.

[9] Shah A, Gaveriya H, Motohashi N, et al. 3,5-Diacetyl-1,4dihydropyridines: synthesis and MDR reversal in tumor cells. Anticancer Res 2000;20:373-7.

[10] Eliopoulos GM, Moellering Jr. RC. Antimicrobial combinations, In: Lorian V, editor. Antibiotics in Laboratory Medicine. 3rd ed., The Williams \& Wilkins Co., Baltimore, MD, USA, 1991. p. 432 92.

[11] Chakrabarty AN, Dastidar SG, Annadurai S, Thakurta AG, Ghosh K. Synergism, indifference and antagonism among nonantibiotics, with antibiotics and chemotherapeutic agents. In: Chakrabarty AN, Molnár J, Dastidar SG, Motohashi N, editors. Non Antibiotics. New Delhi, India: National Institute of Science Communication (NISCOM), 1998:183-200.

[12] Dastidar SG, Ganguly M, Chakrabarty AN, Bhattacharya S. Cross-resistance among non antibiotics with respect to themselves and antibiotics. In: Chakrabarty AN, Molnár J, Dastidar SG, Motohashi N, editors. Non Antibiotics. New Delhi, India: National Institute of Science Communication (NISCOM), 1998:201-8. 